\title{
Blasphemy and Judicial Legitimacy in Indonesia
}

\author{
Adam Tyson \\ University of Leeds
}

\begin{abstract}
When contentious blasphemy laws are pressed into service in fledgling democracies with illiberal tendencies such as Indonesia, critical questions arise about judicial integrity and the political nature of blasphemy trials. Judicial legitimacy in Indonesia is defined according to international standards and conventions. The focus is on judicial propriety rather than the popularity or majoritarian appeal of court decisions. In May 2017 a watershed moment occurred in Indonesia as the former governor of Jakarta Basuki Tjahaja Purnama (popularly known as Ahok) was found guilty of desecrating religion and sentenced to 2 years in prison. Judgments rendered in politicized blasphemy trials such as these fail to meet standards of impartiality, and when discursive transgressions of a blasphemous nature occur there are deep ambiguities of meaning and intent. This paper contends that the revival of blasphemy as a punishable crime relates to political power calculations and electoral opportunities, and offers an analysis of blasphemy in Indonesia through the quasi-historical lens of a discursive crime premised on the fallacy that religious offence threatens public order. Blasphemy trials are further complicated by the fact that religious authorities and Islamic mass organizations in Indonesia have significant influence over judicial processes.
\end{abstract}

On May 9, 2017 a watershed moment occurred in Indonesia as the former governor of Jakarta Basuki Tjahaja Purnama (popularly known as Ahok) was found guilty of desecrating religion and sentenced to 2 years in prison. The blasphemous transgression occurred during a public address at a fishing auction on Pramuka Island, north of the capital Jakarta, during Purnama's 2016 gubernatorial election campaign. As stated in the 636 page North Jakarta District Court decision, the accused intentionally insulted religious leaders and a community of believers, and this deliberate desecration of religion threatens public order. ${ }^{1}$ On his remission from Depok's Mako Brimob prison in January 2019 Purnama struck a 
conciliatory tone. In a hand-written letter published on his Instagram account on January 18, he accepts that it is best to avoid blasphemy charges, rather than challenge the legitimacy of these laws. ${ }^{2}$ In a further plot twist, Purnama thanks God for his election loss and incarceration, stating that he has learned to avoid being rude and arrogant. Purnama has ostensibly come to accept his own guilt, if we take his prison letter at face value, but the risk of capitulation is the emboldening of those willing to accuse high-profile public figures of blasphemy, while taking extrajudicial measures such as mass demonstrations to help achieve a guilty verdict.

Discussions of blasphemy in Indonesia begin with the recognition of the Dutch civil law inheritance. After independence in 1945 the Republic of Indonesia became the largest civil law jurisdiction in the world. Though generally considered more rigid than common law systems, code-based reforms within civil law systems can produce transformational outcomes (Strang 2008). In Indonesia today there is an effort to reclaim history by revising the Dutch-era criminal code, though it is unclear what kind of change to legal culture this entails, and doubts remain about the liberal nature of legal elites given that minority and women's rights are being limited and blasphemy provisions expanded under current legislative proposals (Harsono 2019). When contentious blasphemy laws are pressed into service in fledgling democracies with illiberal tendencies such as Indonesia, critical questions arise about judicial integrity and the political nature of blasphemy trials. Judicial legitimacy in Indonesia is defined according to international standards and conventions. The focus is on judicial propriety rather than the popularity or majoritarian appeal of court decisions. The judgments rendered in politicized blasphemy trials are not impartial and independent, and when discursive transgressions of a blasphemous nature occur there are deep ambiguities of meaning and intent.

This paper contends that the revival of blasphemy as a punishable crime relates to political power calculations and electoral opportunities, and offers an analysis of blasphemy in Indonesia through the quasi-historical lens of a discursive crime premised on the fallacy that religious offence threatens public order. Blasphemy trials are further complicated by the fact that religious authorities and Islamic mass organizations in Indonesia have significant influence over judicial processes. Take for instance the Indonesian Council of Islamic Scholars (Majelis Ulama Indonesia, MUI), an advisory body that has been growing in prominence alongside the Ministry of Religious Affairs since democratization in 1998. 
The conservative MUI has the power to shape Islamic legal traditions, produce fatwa, and control Islamic finance, in a process Lindsey (2012) refers to as "monopolizing Islam."

The conviction of Basuki Tjahaja Purnama is an example of a highprofile politician becoming ensnared in a religious scandal at a time when a risk-averse incumbent president lays the groundwork for re-election. President Joko Widodo's 2019 campaign required complex bargaining with Islamic parties in his coalition. The jostling for power and influence under Indonesian democracy enables outcomes such as the 2010, 2013, and 2018 Constitutional Court decisions to retain Article 156a of the Criminal Code concerning blasphemy, where testimony from Islamic clerics and scholars heavily sways opinion and is seldom refuted or contradicted by authorities. A situation emerges where religious differences are represented by Islamist groups and even some ministers as "deviation" that can be a source of public disorder (Bagir 2013, 3), raising questions of bias and undue influence leading to judicial impropriety.

This paper begins with an examination of blasphemy in comparative historical context, highlighting the risk of complex discursive crimes assuming a despotic power that has profound political and legal effects. One notable risk is the use of blasphemy as a pretext for convictions and reprisals by agents competing for popularity, political influence, and access to the state. The substantive sections of the paper address concerns about judicial procedure and propriety, and demonstrate why blasphemy trials are politicized and thus undermine law enforcement. The approach taken in this paper is that monotheisms are heavily logocentric in their imagining of the profane. All religions "prohibit the greatest profanation they can imagine," and while much of the literature focuses on the Christian world, there are long histories of blasphemy in Buddhist, Hindu, and Islamic traditions (Lawton 1993, 6). Logocentric dialog that defines and focuses on a concept itself, such as the meaning of blasphemy, is arguably of less concern than anthropocentric dialog, the practice of redefining or modifying oneself through dialog about an external object such as blasphemy (Stanghellini 2017, 194). This discursive approach is relevant to politically active Islamist groups such as the conservative Indonesian Council of Islamic Scholars (MUI) who link behavioral modification (doubt, insult) to public disorder and societal collapse. These actors respond by issuing legal interpretations ( fatwa) endorsing blasphemy charges, by exerting pressure on jurists, police, and politicians, and by influencing electoral outcomes through mass mobilizations. 


\section{BLASPHEMY IN COMPARATIVE CONTEXT}

In a global comparative study by Freedom House, blasphemy laws are found to be imprecise, leaving "enormous discretion in the hands of prosecutors, judges, and accusers who may be influenced by political or personal priorities," which is borne out by the evidence in Indonesia (Freedom House 2010, 3). A comparison of Algeria, Egypt, Greece, Indonesia, Malaysia, Pakistan, and Poland shows blasphemy laws to be "vaguely worded and ill-defined," rendering the laws prone to arbitrary application, a situation that "typically give rise to the violation, not the protection, of fundamental human rights" (Freedom House 2010, 1-2). The Pew Research Center (Theodorou 2016) and the U.S. Commission on International Religious Freedom (Fiss and Kestenbaum 2017) find blasphemy laws in 71 of the world's countries and territories. Blasphemy laws are often vague and difficult to code for analytical purposes, but the general finding is that they deviate from international legal standards on human rights and free expression. ${ }^{3}$ Iran and Pakistan have the most severe prohibitions on blasphemy that result in discrimination and abuses of power (Fiss and Kestenbaum 2017, 19), with cases such as the 2011 assassination of former Punjab governor Salman Taseer igniting intense political debate.

The political revival of blasphemy in Indonesia coincides with the country's democratic transition after the resignation of President Suharto in May 1998. Blasphemy prosecutions may seem perplexing given that democratic transitions are generally expected to improve civil rights and standards of justice. As Peterson (2018) finds, an active and illiberal blasphemy law is often used to stifle public criticism of religion in Indonesia. The complex nature of blasphemy means that those who feel judicial processes are tarnished, or punishments are unfair, cannot publicly deny the existence of the crime of blasphemy.

Charges of blasphemy and defamation are similar in that they are complex discursive crimes; immaterial, subjective, and potentially boundless (Streckfuss 2011, 21). According to Joss Marsh (1998, 7), "blasphemy marks the moving boundary line between the permissible and the prohibited," raising the problematic question of who serves as the final legal or moral arbiter in such cases. The risk with laws preventing religious offence is that they have "no rational boundaries" and therefore "threaten creeping repression" (Jones 1980, 139). With these concerns in mind, a landmark attempt by Indonesian legal and human rights activists to repeal the blasphemy law (Law 1/PNPS/1965 concerning the 
prevention of religious abuse, issued by presidential decree) was rejected by the Constitutional Court in 2010 on populist majoritarian grounds of national unity and religious harmony. This contentious decision seems to legitimize Indonesia's blasphemy regime and enables cases such as the 2017 conviction of Basuki Tjahaja Purnama, who now wishes to be called BTP rather than his Hakka Chinese alias Ahok.

Blasphemy, which in Indonesia usually refers to divergence from and offence against Islam (Butt 2018, 407), can serve as a pretext for punishments, convictions, and political reprisals premised on the need to preserve public order. Blasphemy seems anachronistic, and yet the laws passed in its name remain powerful tools for intervention into public affairs, challenging democratic principles such as the right to free expression, tolerance, and diversity. The "conservative turn" in Indonesian Islam since democratization (van Bruinessen 2013) partially explains the political and judicial influence of groups such as the Indonesian Council of Islamic Scholars (MUI) that publicly endorse blasphemy trials, issue conservative religious opinions ( fatwa), and claim to legitimately represent the general Muslim public. Osman and Waikar (2018) see the Purnama case as an indicator of the rise of far-right "uncivil" Islamist groups playing on majoritarian insecurities about the ethnic Chinese and ungodly leftist ideologies.

As with the Muslim majority in Indonesia, Buddhists in Thailand account for at least $90 \%$ of the population, and yet they seem to be trapped in a state of collective anxiety about the future (McCargo 2012, 1). The legitimacy of the Thai state rests on national myths about identity and territory that converge as a form of "Thainess," and Thai Buddhists in such a highly charged political environment are prone to intolerance toward Muslim and Christian minorities (McCargo 2012, 18). The perceived threat of minority domination (by Chinese Christians in Indonesia, Malay Muslims in Thailand) seems to be spreading, which partially explains the prevalence of discursive crimes such as blasphemy in ethnically divided countries. In this context, religious incitement leading to prosecutions are often caused by political agents seeking to profit by persuasion, deploying powerful "injustice frames" that highlight intolerable offences such as blasphemy (George 2016, 11). The fact that some people will inevitably, and often deliberately, find offense in processes of free inquiry that may include ridicule seems insufficient reason to limit public debates on religion. And yet blasphemy, which has gradually shifted from protecting to policing belief, challenges the fundamental right 
to free thought and expression, and creates risks in diverse nations such as Indonesia, Pakistan, and Thailand.

Commenting on the persistence of blasphemy laws throughout the world, David Lawton $(1993,10)$ suggests that "the relation between blasphemy and sedition is one structural reason why the law is slow to give up the offence of blasphemy." David Nash $(2007,10)$ finds that the history of blasphemy follows a series of chronological shifts, from "conceptions of the damaged community of believers, to the damaged social and political peace, arriving finally at the wounded feelings and convictions of modern individuals." Peter Jones $(1980,131)$ suggests that the legal rationale for blasphemy has developed in a similar way, beginning with efforts to criminalize contemptuous utterances concerning the Deity. This evolved into a campaign to give legal protection to the doctrines and institutions of the established faith, followed by the need to protect the state against sedition. The next iteration was to protect the fabric of society and public morality against threats to public order, and then to protect individuals from that which offends their religious sensibilities. We now seem to have entered an era of "hate spin," where religious incitement or "manufactured indignation" is used as a political strategy that "exploits group identity to mobilize supporters and coerce opponents" (George 2016, 4). One of the most prolific hate spin agents in Indonesia is the hardline Islamic Defenders Front (Front Pembela Islam, FPI), whose members specifically targeted Purnama because of his minority status and his attempt to ban the FPI during his tenure as governor of Jakarta (Telle 2018a).

David Lawton $(1993,3)$ contends that "blasphemy stands for whatever society most abhors and has the power to prosecute," although it seems blasphemy is more of a reflection of what the powerful, speaking on behalf of society, abhor, and fear. Some conservative Islamist organizations in Indonesia seek to gain political influence through street demonstrations, legal actions as well as social media campaigns to defend religion while also manufacturing outrage, thus increasing the potential for the criminalization of blasphemy. The appropriation of blasphemy to serve as an instrument of discipline and social control marks the end of blasphemy as a literal crime against God or scripture. The repurposing of religious offence by state and non-state organizations to impose order and punish transgression should invoke Henry Lea's $(1906,6)$ warning about the "spiritual despotism" of those in power during the Spanish Inquisition.

Indonesia is said to follow Dutch and Swiss models of religious freedom that emphasize multi-religious accommodation and formal state 
recognition, as opposed to American and French separations of church and state (Hefner 2016, 61). Where there is a strong libertarian tradition, such as in the United States, it generally transpires that individual expression can only be "prevented and punished when there is a strict causal connection between speech and subsequent action or harm" (Post 1988, 322). For such restrictions to be imposed there must be a causal strictness that maximizes the amount of constitutionally protected free speech (Post 1988, 322). The First Amendment guarantees the highest threshold of free speech in the world, and the Brandenburg test is used to determine whether speech is directed to and likely to incite imminent lawless action or violence (Calvert 2019). ${ }^{4}$ Pertinent to religious harmony and offence, the basic rationale for U.S. First Amendment constitutional safeguards is that "line drawing between offensive and non-offensive speech is too complex and subjective to provide rational distinctions" (Calvert and Richards 2002, 679). One can tentatively conclude, therefore, that "it is not for the government to dictate rules of civility and social mores of speech interactions through laws that tell citizens what they can and cannot say" (Calvert and Richards 2002, 679).

The necessity of religion to social stability and public morality, as claimed by the Indonesian Council of Islamic Scholars and others, is deeply ambiguous. Taking a comparative look at the United Kingdom, in early the post-war period Lord Denning $(1949,46)$ sought to put an end to medieval debates about blasphemy and public order by proclaiming the offence "a dead letter." An attempt by Lord Willis to enact a bill in 1979 abolishing blasphemy caused some members of UK House of Lords to claim that blasphemy protects "deeply rooted values in society," without which society is eroded, nebulous and without purpose, where "just anything goes" (Jones 1980, 132). Just anything goes is reminiscent of the dilemma raised in Guy Thorne's 1903 bestselling novel When It Was Dark. Thorne advanced the idea that the world's moral order depends on the divine revelation of Christianity (Kilcrease 2014). The basic plot of the book is that, on hearing the news that Christ did not rise from the dead (the resurrection was a hoax), people suddenly found themselves in world without belief, a world with no moral order, and wars, genocide and riots spontaneously broke out on a global scale. This scale of spontaneous moral degeneration ("just anything goes") is clearly exaggerated, although there is a case to be made that in the absence of religion one's sense of community is diminished.

A contemporary argument by Cherian George $(2016,18)$ is "the myth of spontaneous rage," which focuses on the role of political agents and 
entrepreneurs seeking to incite violence or mobilize masses, and the ways in which these agents profit when jurists, police and the media treat them as genuine spokespersons of their communities. It follows that blasphemy will remain a coercive tool, working alongside other forms of censure and control, so long as churches, mosques, and synagogues have worshippers and liturgical responsibilities that can be exploited. There are related concerns that debates about offence and public order are not conducted in a robust and neutral "marketplace of ideas," as some jurists suggest, but rather in a market that is skewed in favor of an entrenched power structure and ideology (Ingber 1984, 85). The concept of blasphemy regimes introduced below helps explain the particular nature of a country's entrenched power structure and ideology.

\section{JUDICIAL LEGITIMACY UNDER BLASPHEMY REGIMES}

Religion has been a key unifying factor in Indonesia's post-colonial development, for instance taking the form of "godly nationalism" (an imagined community of believers) in the 1940s (Menchik 2014, 594). By this reading, the archetypal good Indonesian citizen is one who believes in God and behaves in accordance with religious beliefs and values. Liberal ideals have never been a dominant force in Indonesian politics and statecraft. When President Suharto was in power (1966-1998), the "smiling face" of Indonesian Islam was dominated by modernist discourses that worked in tandem with the authoritarian developmental state (van Bruinessen 2013, 1). In the early New Order period under Suharto religion was used as a counterforce against communism and leftist ideology, while strengthening the president's political position through co-optation and vote mobilization (Picard 2011, 14). With atheism banned, all citizens were (and continue to be) obliged to follow a state-sanctioned religion. The Ministry of Religious Affairs and Indonesian Council of Islamic Scholars (MUI) were enlisted to shore up Muslim majority support for Suharto by balancing other core factions such as the armed forces. Since democratization in 1998 the state has become increasingly involved "in the firm demarcation of religious orthodoxy," leading to truncated religious pluralism and the hardening of political stances on religious deviance in Indonesia (Menchik 2014, 594).

In Muslim majority Indonesia there is no single, absolute religious authority or arbiter, though allegations of blasphemy are often brought to court by the MUI. As virtually the sole expert witness in cases of 
blasphemy in relation to Islam, police, prosecutors, and judges tend to defer to the MUI, which was first established during the Suharto regime to provide religious-based support for its authoritarian policies. The subsequent post-1998 strengthening of the MUI as a quasi-official body, particularly under the administration of President Yudhoyono (2004-2014), enables the MUI to claim special authority to deal with blasphemy cases and define orthodoxy (Olle 2009, 106). The increasing prominence of the MUI in elections under the current Joko Widodo administration indicates the co-option of blasphemy by political actors with utilitarian views of religion.

Stewart Fenwick $(2017,73)$ identifies the existence of a blasphemy regime in Indonesia, which refers to a regime under which religious offence is redirected toward the protection of institutions and the state, rather than the protection of religious communities per se. To evaluate Fenwick's (2017) claims about a blasphemy regime that serves to buttress the Indonesian state, appease religious factions within the country, and limit the scope for public discourse by silencing religious critique, this paper makes comparative reference to the "defamation regime" in Thailand. According to David Streckfuss (2011, 24), a defamation regime has the following features: frequent use of defamation-based laws by the state; little reluctance on the part of police to charge, prosecutors to try, and courts to accept defamation-based cases; little restraint on the part of citizens in accusing others of defamation-based offenses; little or no exemption from guilt allowed by courts; and weak constitutional provisions ensuring freedom of speech. Each of these features is prevalent in Indonesia, raising questions about judicial integrity and the application of the law when blasphemy charges are brought to trial.

\section{Frequent Use of Blasphemy Laws by the State}

Considering the increasing salience of blasphemy cases, and the modest performance of Islamic parties such as the National Awakening Party (Partai Kebangkitan Bangsa, PKB) in recent general elections, there appears to be a paradox in Indonesian politics. One explanation is that both secular and religious political parties defend religious beliefs and engage in Islamization (Lorch 2019, 260), while risk aversion tends to prevent parties from challenging the blasphemy laws. As Marcus Mietzner (2018) suggests, the calculated Islamist mobilizations against former governor Purnama, particularly the December 2, 2016 mass 
incident known as the "212 movement" involving hundreds of thousands of protestors in Jakarta, have reopened debates about religious polarization and the resurgence of populism in Indonesia. There is a risk of blasphemy laws being used to silence political opponents, of blasphemy charges being fabricated, and of religious groups exploiting blasphemy to justify attacks on minorities, which tends to foster a hostile and intolerant political environment (Freedom House 2010, 1-2).

Indonesia's blasphemy provision is found in Article 156a of the Dutchinspired Criminal Code, which is based on Law 1/PNPS/1965 concerning the prevention of religious abuse promulgated by Indonesia's first president Sukarno. Blasphemy was formalized during the Cold War period, a volatile time in Indonesian politics when the Indonesian Communist Party was on the rise and the spread of mysticism threatened the country's five (now six) officially recognized religions (Crouch 2012). According to a study by Indonesia's Setara Institute, Law 1/PNPS/1965 and its implementing regulations concerning religion are held to be incongruent with the Indonesian constitution (Halili 2016, 7-8). Article 156a of the Criminal Code assigns up to 5 years imprisonment for those who deliberately and publicly make a statement or perform an act that (a) constitutes animosity toward, or dishonors, a religion adhered to in Indonesia, or (b) is intended to prevent a person from adhering to any religion based on the Almighty God (Butt and Lindsey 2012). While the question about frequency of use is subjective, we know that there has been a rise in blasphemy cases reaching the Indonesian courts since 1998. A report by the Indonesian Legal Resources Centre (Sihombing, Siti Aminah, and Khoirul Roziqin 2012, 11) finds that under Suharto's authoritarian regime (1966-1998) there were only three blasphemy trials, whereas Melissa Crouch $(2017,239)$ estimates more than 130 blasphemy convictions between 1998 and 2012. Given the size of Indonesia, this is not a prolific use of the blasphemy law, but it certainly marks an intensification of cases in the post-Suharto era, and serves as a reminder of the power that dormant laws can have when invoked by authorities or exploited by politically expedient organizations.

\section{Little Reluctance to Accuse or Prosecute}

There are risks that a constitution such as Indonesia's empowers rather than restrains the will of the majority, which "may deepen religious cleavages and trigger widespread conflict" (Shah 2014, 262). The risks are very 
real, although the limited number of blasphemy cases suggests some reluctance by the police to pursue these cases, and perhaps the salience of alternative, extra-legal mechanisms for dealing with blasphemy disputes. Blasphemy trials, when they do occur, are often politically motivated or driven by the fear of repercussions if the police appear lenient or unwilling to make arrests. It seems that the crime of blasphemy has replaced the crime of subversion that was common during the authoritarian New Order era under Suharto (Lindsey and Crouch 2013, 635). The police appear to be caught between their formal protect and serve community functions, and their more contentious role as morality defenders that includes religious observance and the maintenance of national unity (often at the expense of diversity).

The arrest of Donald Ignatius Suyanto, a chef living in Bali, on July 27, 2017 gives the general impression of the prevailing situation in Indonesia. Suyanto, better known as Donald Bali since his arrest, stands accused of blasphemy for posting a YouTube video that questions the shahada, a statement of faith for Muslims that there is no God but Allah, and that Muhammad is their messenger (Bali Post 2017). The arrest was prompted by complaints made by bloggers that police and cybercrime units decided (or felt pressured) to pursue, which shows that free expression, opinion, and thought is always at risk when people claim religious offence. Here we witness the powers of consensus and majoritarian coercion that impede law enforcement and judicial propriety. Merlyna Lim (2017) finds that judicial independence frequently gives way to public pressure in Indonesia.

Vice President and MUI chairman Ma'ruf Amin's fatwa against Purnama accused the former governor of insulting (penghinaan) the Qur'an. The police may have initially been reluctant to arrest Purnama given his notoriety and strong political connection to President Joko Widodo, and there was never a consensus as to how to proceed, although after interviewing 29 witnesses and 39 experts from various fields, formal police charges were issued by Ari Dono Sukmanto, Head of Criminal Investigations. Mass protests in Jakarta led by the Islamic Defenders Front and the Movement to Safeguard the MUI's Fatwa were likely a key factor behind the police decision (Singghi 2019, 31). Tomsa (2017, 152) contends that "politically motivated blasphemy charges" were brought against Purnama by a police force seemingly bowing to public and elite pressure. ${ }^{5}$ President Joko Widodo worried that the Muslim backlash against Purnama would affect his own popularity and electability. Purnama was thus a necessary political sacrifice, and in a bid to shore 
up political support from Islamic mass organizations and political parties ahead of the general election in April 2019, Ma'ruf Amin was handed the vice presidency.

\section{No Exemption from Guilt}

Charlotte Setijadi (2017) found at least 106 blasphemy prosecutions in Indonesia since 2005 , with a near- $100 \%$ conviction rate in blasphemy cases that mainly punish members of a religious minority. An account of the legal representation provided by the Indonesian Legal Aid Institute (Lembaga Bantuan Hukum, LBH) to citizens facing communal harassment and state actions since the democratic transition in 1998 shows that, in blasphemy cases involving religious offences covered by Article 156a, the LBH has yet to win an acquittal (Lindsey and Crouch 2013, 634). It is argued that the LBH are engaged in a politicallycharged and theatrical form of cause lawyering, where public interest litigation is used to defend religious freedom (Lindsey and Crouch 2013, 636). In the case of Abdullah, an elderly Muslim farmer living in East Lombok with an overactive imagination, the District Court in Selong passed down a supposedly lenient 1-year prison sentence that took into account his advanced age and willingness to repent (Telle 2018b). Abdullah is guilty of thought crimes and utterances that fall under the label of blasphemy (he claimed to receive revelations from the Angel Gabriel), and while mitigating circumstances were accepted by the court, there can be no exemption from guilt. Similar conclusions can be drawn from the 2018 Medan District Court decision to sentence Meliana, a Chinese Buddhist housewife, to 18 months in prison for her complaints about the volume of the adhan, or Muslim call to prayer (Suryadinata 2019).

\section{Weak Constitutional Provisions Ensuring Freedom of Speech}

Free speech is covered by the Second Amendment to the Indonesian Constitution passed in 2000 that created a special charter of human rights inspired by the Universal Declaration of Human Rights. Articles $28 \mathrm{E}$ and $28 \mathrm{I}$ of the amended constitution contain religious freedom provisions as well as restrictions on rights and freedoms that can be imposed in accordance with religious values (Faiz 2016). While Article 29 guarantees freedom of worship for all citizens, there is no place for non-believers and 
thus no real freedom from religion. Non-believers and wrong-believers (deviants) are not afforded the same legal protections as true believers in Indonesia, thus raising concerns about outsider jurisprudence, although everyone is equally vulnerable to accusations of blasphemy. For this reason, a group of civil society organizations in Indonesia brought a case to the Constitutional Court in 2009 in the hope of abolishing Article 156a of the Criminal Code and restoring judicial propriety. This challenge, and subsequent cases heard by the Constitutional Court concerning the rights of Shia Muslims and Ahmadiyyah, failed to abolish criminal blasphemy, which is indicative of the salience of religious deference as well as deep suspicions between religious groups (Crouch 2016).

\section{THE 2009-2010 CONSTITUTIONAL COURT JUDICIAL REVIEW}

In 2009 the Indonesian Legal Aid Institute (LBH), along with prominent legal and human rights organizations in Indonesia such as Imparsial, ELSAM, and the Setara Institute, initiated a judicial review of Law 1/ PNPS/1965 and Criminal Code Article 156a. The legal applicants argued that blasphemy provisions contravene the constitutional right to religious freedom in Indonesia (Crouch 2012, 1). In a 2011 Amicus published by human rights experts from Cairo and London, Law 1/PNPS/ 1965 concerning the prevention of religious abuse is determined to be "fundamentally incompatible with Indonesia's obligations under international human rights law" (Amicus 2011, 3). ${ }^{6}$ Article 156a, along with all other criminal code provisions preventing the abuse of religion, should be repealed because they violate freedom of expression, freedom of thought, conscience and religion, and equality before the law (Amicus 2011, 4).

Since its establishment in 2003 the Constitutional Court of Indonesia has been an activist court, seeking to strengthen democracy by improving oversight and conducting judicial review in a highly public forum, although the Court faces hostility from politicians and has been forced to make strategic adjustments to "soften the impact of its decisions" (Butt 2012, 108). The Court's contentious decision to retain Article 156a helps legitimize Indonesia's blasphemy regime at the expense of fair and impartial law enforcement. The 2010 decision reveals an "overarching sense of obligation to respect religion" as well as signs of "weakness" (Fenwick 2017, 185) in public and judicial reasoning in Indonesia. The Constitutional Court heard questions about freedom of religion and 
the competency of the state, and some witnesses shared the Amici's position that, with very few exceptions (incitement being the most prominent), it is not for the government to tell their citizens what they can or cannot say, think or believe. Since 2010 the charge of blasphemy has been reviewed a number of times by the Constitutional Court, most recently in 2018 when the Court rejected a petition by members of the Ahmadiyyah community to abolish Article 156a.

Franz Magnis Suseno, a well-known Jesuit priest and professor of philosophy at STF Driyarkara, contends that difference of belief is not blasphemy, that religious deviance is relative, a matter of opinion not fact, that rests outside of the competence of the court and state authorities (Constitutional Court of Indonesia 2010, 253). In a warning against the repressive nature of blasphemy laws, Suseno argues that fringe groups such as Jehovah's Witnesses (and for that matter the Ahmadiyya sect) have the right to believe whatever they wish to believe regardless of the offence caused to Catholic or Sunni majorities, or any nominal idea of majoritarian consensus. As Kari Telle (2018b, 371) points out, the unanswered (and probably unanswerable) theological question about the "true" form of Islam has divided Muslims throughout Islamic history, but in Indonesia today the civil courts "are increasingly adjudicating such theological disputes." Given these legal trends, it is worth recalling Henry Lea's $(1906,6)$ historical conception of "spiritual despotism" that arises when the power of religion is misused for political purposes, or turned into an instrument of oppression. According to the Brandenburg test in the United States, courts do not have the competence to adjudicate on matters of religious truth or deviance, which means that jurists should not attempt to draw the lines that separate blasphemy from inquiry, ridicule, or doubt.

Contrary to Franz Magnis Suseno's interpretation, the majority of expert witness submissions to the Constitutional Court took the pluralist position that more protection for all religious groups is in fact needed. But the problem of adjudication has not been resolved. It remains to be seen how exactly a judge or a cleric or a politician can claim to know, with the certainty of truth, when religious believers deviate from the central tenets of their faith, whether this deviation is deliberate or accidental, to what extent deviation can be considered a form of injury to communities of believers, and on what grounds people are incited to violence (Fenwick 2017, 63). Prominent defenders of the blasphemy law such as the Indonesian Council of Islamic Scholars (MUI) cite well-rehearsed arguments about the need to protect society and public morals, which is 
reminiscent of the exaggerated UK House of Lords claim in 1979 that blasphemy protects "deeply rooted values in society," without which "just anything goes" (Jones 1980, 132). The MUI claim is that the abolishment of Article 156a will lead to levels of religious deviance that will likely cause extraordinary turmoil and strife, and possibly even the destruction of the public order (Fenwick 2017, 64). It is hard to imagine a religious justification for the deliberate and willful destruction of the public order, which suggests the MUI had something else in mind when it made its submission to the Constitutional Court. We know that since the democratic transition in 1998 the MUI has been seeking to monopolize its position as the leading fatwa-maker in Indonesia, which includes the authoritative (or final) say over "correct" forms of Islamic belief (Hasyim 2015).

\section{THE 2016-2017 BLASPHEMY TRIAL OF BASUKI TJAHAJA PURNAMA}

In September 2012 Joko Widodo (who goes by the nickname Jokowi) and Basuki Tjahaja Purnama were elected as governor and deputy governor of Jakarta. When Jokowi cut his term short to run for (and win) the presidency in 2014, Purnama, a former mining consultant who began his political career in the remote island of Belitung, inherited the office of governor of Jakarta. In November 2014, 1 month after Jokowi was sworn in as president, Purnama joined Jokowi and many other national political leaders on the popular Metro TV program Mata Najwa, during an episode branded as a "celebration" (merayakan) of Indonesia. Purnama was in the spotlight for one segment of the show and was given the chance to ask former president Megawati Sukarnoputri a series of soft questions about current political trends. He quickly went off script, asking Megawati why she backed Jokowi's presidential bid, when she knew full well that Jokowi's success would mean placing a non-Muslim leader of Chinese descent in the governor's seat, a maneuver that was politically risky for her and was quite unpopular in many parts of the country. ${ }^{7}$ Purnama suggested that, given Megawati's standing as a respected elder and key political figure in contemporary Indonesia, she could defend his inauguration by giving some context to the debate and helping the public understand the history of Indonesian nationalism and pluralism, but his appeal fell on deaf ears. ${ }^{8}$ 
The contentious rise of Purnama was met by a political backlash instigated by some national elites who positioned themselves as defenders of "indigenous" ( pribumi) Indonesians, in what Leo Suryadinata (2017) calls the re-emergence of pribumi-ism. The numerical supremacy of Indonesia's pribumi population is not enough prevent the spread of anxieties and rumors about the latent threat of ethnic Chinese political and economic dominance (Cochrane 2014). ${ }^{9}$ Despite the personalized attacks made against his identity and character, Purnama maintained high approval ratings throughout his term in office. In September 2016, during the gubernatorial election campaign, a YouTube video emerged showing Purnama addressing residents of Pramuka Island just off the coast of Jakarta. Purnama warned people not to be deceived (dibohongi) by those using Al-Maidah verse 51 to undermine his candidacy. This is a Quranic verse that can be interpreted as forbidding non-Muslims from leading Muslims, meaning that Jakarta's Muslims cannot vote for Purnama, and the verse focuses on the unity and loyalty of the Muslim community (ummah).

In November 2017, an academic named Buni Yani was sentenced to 18 months in prison for uploading a 30 second clip from the blasphemous Purnama video, as well as circulating an edited transcription of Purnama's speech that led to public outcry and was found to constitute hate speech by a district court in Bandung, West Java (Lazuardi 2017). In response to Buni Yani's edited video and transcript, the provincial branch of the Indonesian Council of Islamic Scholars in South Sumatra filed a police report about Purnama's supposedly blasphemous comments in 2016, and this charge was endorsed by mass religious organizations throughout the country, including the militant Islamic Defenders Front, Hizbut Tahrir Indonesia, and Muhammadiyah youth groups (Gunn 2018). Mass organizations such as these are known to be influential power brokers in democratic Indonesia, willing and able to weaponize religion to affect political outcomes (Nastiti and Ratri 2018). The supposed insult to Islam and threat to Muslim unity came from Purnama, a Chinese Christian double minority who is a close associate of President Jokowi and has spent most of his political career fighting corruption, reforming bureaucracies, and insisting upon transparency in government.

President Jokowi's rivals sought to turn the 2016 Jakarta elections into a proxy battle for the presidential race in 2019 (Mietzner 2017). Former president Susilo Bambang Yudhoyono endorsed his son Agus, while presidential aspirant Prabowo Subianto backed Anies Baswedan in the race against Purnama. Faced with the very real prospect of Purnama securing 
a popular mandate to govern Jakarta and then running for vice president in 2019, Islamists seized the opportunity to attack Purnama for his alleged blasphemy (Mietzner 2018, 272). When blasphemy charges were brought against Purnama for his Al-Maidah reference, he already had a reputation as an abrasive, at times even foul-mouthed speaker, though his performance as governor earned him widespread respect in middleand upper-class districts of Jakarta, as well as international plaudits (Hatherell and Welsh 2017). Part of Purnama's reform agenda included an urban flood prevention system in Jakarta that required large-scale evictions of poor families living near riverbanks, which led Saskia Schafer (2017) to conclude that the tensions surrounding Purnama are explained by the complex interplay of grievances, piety, and anger. Some claim that the former governor's aggressive enforcement of evictions benefits middle-class constituents and property developers while reinforcing the structural disadvantage of the poor and compounding their sense of betrayal (Wilson 2016).

Data from professional polling agencies such as Indikator and Saiful Mujani suggested that Purnama was going to win the first round of elections in February 2017 despite the ongoing blasphemy trial, which turned out to be true, but that he would lose the second-round runoff because voters who supported Agus Yudhoyono (the losing candidate) in the first round would migrate to Purnama's rivals. Anies Baswedan and his deputy seem to have won the electoral runoff by capitalizing on anxieties about electing a non-Muslim, ethnically Chinese governor and by making extravagant spending promises to improve social welfare in Jakarta (Anindya 2017). Though difficult to quantify, the blasphemy trial certainly undermined Purnama's campaign and worked in his opponent's favor, particularly during the second-round electoral runoff that took place between February and April 2017. ${ }^{10}$

A survey experiment conducted by Nathanael Sumaktoyo (2017) during the Jakarta elections determined that the most significant decline in support for Purnama occurred when voters were reminded that Purnama is a Chinese Indonesian minority. The findings suggest that Purnama's ethnicity is more politically significant than his religion. Sumaktoyo's randomized sampling of voters in Jakarta shows that being a Christian did not significantly impact on the levels of support for Purnama, although this survey did not account for the likely vote swing against a blasphemous evangelical Christian, which is a different proposition altogether.

After losing the gubernatorial election Purnama was given a 2-year prison sentence by the North Jakarta District Court, which raises two 
questions related to Indonesia's Criminal Code. First, in what way did Purnama's reference to Al-Maidah verse 51 constitute animosity toward Islam? Second, how can it be determined that his statement was intended to prevent someone from adhering to Islam? If the procedural integrity of the Indonesian judiciary is to be maintained, at least one of these contraventions must have been proved beyond a reasonable doubt. There is little in the trial transcripts or head judge Dwiarso Budi Santiarto's final verdict that suggests these legal criteria have been definitively met. But even if one believes that this procedural test has been met, it still does not resolve the substantive question as to whether there should have been a trial of this kind in the first place.

In a review of 37 blasphemy cases involving charges under Article 156a, the Indonesian Legal Resources Centre raises serious concerns about legal uncertainty and the improper application of the law by judges who cannot remain neutral in cases involving the desecration (penodaan) of religion (Sihombing, Siti Aminah, and Khoirul Roziqin 2012, 78). An updated study of 63 blasphemy cases, including 11 prosecutions from 2014, highlights the intervention of religious organizations such as the MUI and the tendency of jurists to base their judgments on information provided by these organizations-the same religious authorities who issue fatwa in the first place-thus ensuring a guilty verdict (Aminah and Roziqin 2015). Andhika Prayoga's (2015) analysis of the legal proceedings in two blasphemy cases from Sulawesi and Sumatra casts doubt upon the professional conduct of judges, and the author concludes that judges in blasphemy cases are heavily swayed by their private religious beliefs and by the fatwa issued by clerics. It is difficult for judges to resist the social pressure to prosecute, and nearly impossible for them to remain objective in blasphemy trials. These conclusions are reinforced by the Indonesian Institute for the Independent Judiciary, who analyzed 27 blasphemy cases and found judicial institutions do not act in a neutral and objective manner, leading to mistakes in law enforcement, erroneous legal interpretation, and infringements of fair trial principles (Cohen 2018, 99).

\section{CONCLUSION}

Blasphemy has been examined in this paper as a discursive crime that is politically motivated and can lead to serious abuses of power. With reference to the trial of former governor Basuki Tjahaja Purnama, better known as Ahok, this paper demonstrates that blasphemy charges tend to 
undermine judicial legitimacy and influence electoral outcomes in Indonesia. The political revival of blasphemy as a punishable crime places near-impossible expectations on jurists, politicians, and clerics who are asked to safeguard religion by imposing what appear to be arbitrary limits on freedom of expression. Law enforcement faces considerable pressure from conservative Islamist groups claiming to speak on behalf of Indonesia's Muslim majority while bidding for power, parliamentary representation, and popularity. Consequently, citizens in Indonesia risk facing the double burden of curtailments to their free expression as well as restrictions on their religious beliefs under the current blasphemy regime.

In this paper, judicial legitimacy in Indonesia is tested against international standards and conventions, with a focus on judicial propriety rather than the level of majoritarian support for court decisions in blasphemy cases. There is compelling evidence that judgments rendered in politicized blasphemy trials are not impartial and independent (Sihombing, Siti Aminah, and Khoirul Roziqin 2012; Aminah and Roziqin 2015; Prayoga 2015; Halili 2016; Cohen 2018). When discursive transgressions of a blasphemous nature are reported to police, there are significant ambiguities of meaning and intent. Politically active Islamist groups and authorities often seek to legitimize blasphemy charges under the pretense that punishments preserve public order and religious harmony. Blasphemy laws are constructed and pressed into service to maintain a prevailing socio-political order constructed in majoritarian terms, in which Indonesia's minorities are partial citizens and Islam is made representative of a presumed conservative majority. Guilty parties are prosecuted to secure outcomes that have little to do with the crime, and in most cases the crime itself lacks any intent (mens rea) or clear evidence of harm, raising the specter of punitive measures for victimless crimes.

The conditions under which blasphemy laws are pressed into service in democracies such as Indonesia are related to political power calculations and electoral opportunities, as well as levels of recognition afforded to groups such as the conservative Indonesian Council of Islamic Scholars (MUI) that influence judicial processes. Testimony from the MUI, whose chairman Ma'ruf Amin is now the vice president of the Republic of Indonesia, heavily sways legal and public opinion, and is seldom refuted or contradicted by authorities. While the MUI and their supporters may feel vindicated, the outcomes of blasphemy trials place significant strain on the judicial system and democratic process.

If international legal standards of due process and propriety are applied, as called for by Indonesian groups such as the Legal Aid Institute (LBH), 
Imparsial, ELSAM, and the Setara Institute, one finds reasonable doubt, uncertainty of intent, and inconclusive evidence of harm and insult in the Purnama case. Despite the ruling of the North Jakarta District Court in the Purnama case, and the landmark 2010 decision of the Constitutional Court to retain the blasphemy law, one could reasonably argue that Purnama's campaign appeal against the misuse of Al-Maidah verse 51 was in fact an effort to preserve (not undermine) the integrity of the Quranic verse, and was in no way a malicious attack against religious beliefs, believers, or institutions. Indeed, some senior members of the Islamic mass organization Nahdlatul Ulama have argued against Purnama's blasphemy conviction. The prosecutor's claim that Purnama's reference to the Quran injured Muslims and threatened to undermine public order is difficult to prove beyond doubt, and the question of voter preferences and conduct in elections is the mandate of the Election Commission, not the Indonesian Council of Islamic Scholars. These contradictions have yet to be resolved, and the 2019 proposal in the House of Representatives to revise the Dutch-era Criminal Code is set to expand the scope for blasphemy charges in Indonesia, meaning observers are likely to witness even more problematic trials such as Purnama's in the coming years.

\section{Financial support}

No research grants are associated with this paper.

\section{Conflict of interest}

No research grants are associated with this paper.

\section{NOTES}

1. North Jakarta District Court Decision Number 1537/Pid.B/2016/PN.Jkt Utr.

2. Basuki Tjahaja Purnama's Instagram post is available at: https://www.instagram.com/p/ BswNAD5HdhH/.

3. The key indicators used by the U.S. Commission on International Religion to score countries are freedoms (of expression, belief), principle of legality, severity of penalty, discrimination, state religion protections, forum limitations, and hierarchy of the law.

4. In reference to the U.S. Supreme Court ruling in the 1969 Brandenburg versus Ohio case.

5. Similar trends have been observed in Pakistan, where there are reports of police facing public pressure and "repercussions from violent and restless Islamic mobs" if they fail to make arrests following accusations of blasphemy (Holzaepfel 2014, 597).

6. The Amicus brief on Constitutional Court of Indonesia case number 140/PUU-VII/2009 concerning the prevention of religious abuse was jointly produced by Article 19, Amnesty 
International, the Egyptian Initiative for Personal Rights, and the Cairo Institute for Human Rights Studies.

7. YouTube, "Mata Najwa: Merayakan Indonesia 2014 [Mata Najwa: Celebrate Indonesia 2014]", November 22, 2014, available at: https://www.youtube.com/watch?v=pKSoPki7sss.

8. YouTube, "Mata Najwa." There are multiple YouTube clips of the November 22, 2014 Mata Najwa program, but I could only find one video (with poor audio quality) that did not remove Basuki Tjahaja Purnama critical question about his ethnicity. Purnama's televised statement, in full, reads as follows: Ini yang masalah sekarang, karna banyak "publik" [orang] pikir belum saatnya orang turunan Tionghoa, non-Muslim lagi mimpin Ibu kota [Jakarta]. Berarti Ibu [Megawati] pasti tahu, kalau Pak Jokowi Ibu yakin jadi presiden, pasti saya jadi gubernur. Nah, pandangan Ibu tentang nasionalisme ini perlu, mungkin Ibu ceritakan supaya orang bisa mengerti, minimal belain saya baru dilantik.

9. Jemma Purdey (2006) identified a pattern of violence against Indonesia's ethnic Chinese communities, who since the early settlements of traders and merchants from provinces such as Guangzhou and Fujian have suffered because of their symbolic otherness (languages, religions, customs), and their disproportionate control of private business capital.

10. The pairing of Anies Baswedan and Sandiaga Uno won convincingly, with $58 \%$ of the vote during the second-round runoff in April 2017.

\section{REFERENCES}

Amicus. 2011. Judicial Review of Law Number 1/PNPS/1965 Concerning the Prevention of Religious Abuse and/or Defamation.

Aminah, Siti, and Muhammad Khoirur Roziqin. 2015. "Pemantauan Kasus Kasus Penodaan Agama di Indonesia Periode 2012-2014 [Monitoring Blasphemy Cases in Indonesia for the Period 2012-2014]." Jurnal Keadlian Sosial 5: 25-59.

Anindya, Chaula R. 2017. "2017 Jakarta Election-Alternative View: Beyond Religion." RSIS Commentaries No. 078. Singapore: Nanyang Technological University.

Bagir, Zainal Abidin. 2013. "Defamation of Religion Law in Post-Reformasi Indonesia: Is Revision Possible?" Australian Journal of Asian Law 13 (2): 1-16.

Bali Post. 2017. "Video: Diduga Menista Agama, Pemilik Akun Donald Bali Ditangkap [Video: Suspected of Insulting Religion, Account Owner Donald Bali is Arrested]." July 26. http://www.balipost.com/news/2017/07/26/16098/Diduga-Menista-Agama, Pemilik-Akun...html (Accessed June 7, 2019).

Butt, Simon. 2012. "Indonesia's Constitutional Court: Conservative Activist or Strategic Operator?" In The Judicialization of Politics in Asia, ed. Björn Dressel. Abingdon: Routledge, 98-116.

Butt, Simon. 2018. "Religious Conservatism, Islamic Criminal Law and the Judiciary in Indonesia: A Tale of Three Courts." The Journal of Legal Pluralism and Unofficial Law 50 (3): 402-434.

Butt, Simon, and Tim Lindsey. 2012. The Constitution of Indonesia: A Contextual Analysis. Oxford: Hart Publishing.

Calvert, Clay. 2019. "First Amendment Envelope Pushers: Revisiting the Incitement-toViolence Test with Messrs. Brandenburg, Trump, \& Spencer." Connecticut Law Review 51 (1): 117-154.

Calvert, Clay, and Robert D. Richards. 2002. "Free Speech and the Right to Offend: Old Wars, New Battles, Different Media." Georgia State University Law Review 18 (3): 671-719.

Cochrane, Joe. 2014. "An ethnic Chinese Christian, breaking barriers in Indonesia." The New York Times. November 22. https://www.nytimes.com/2014/11/23/world/asia/anethnic-chinese-christian-breaking-barriers-in-indonesia.html (Accessed June 7, 2019). 
Cohen, David. 2018. Interpretations of Article 156a of the Indonesian Criminal Code on Blasphemy and Religious Defamation (A Legal and Human Rights Analysis). Jakarta: Indonesian Institute for the Independent Judiciary.

Constitutional Court of Indonesia. 2010. Putusan Nomor 140/PUU-VII/2009. Jakarta: Mahkamah Konstitusi Republik Indonesia.

Crouch, Melissa. 2012. "Law and Religion in Indonesia: The Constitutional Court and the Blasphemy Law." Asian Journal of Comparative Law 7: 1-46.

Crouch, Melissa. 2016. "Constitutionalism, Islam and the Practice of Religious Deference: The Case of the Indonesian Constitutional Court." Australian Journal of Indonesian Law 16 (2): 1-15.

Crouch, Melissa. 2017. "Negotiating Legal Pluralism in Court: Fatwa and the Crime of Blasphemy in Indonesia." In Pluralism, Transnationalism and Culture in Asian Law, ed. Gary F. Bell. Singapore: ISEAS, 231-256.

Denning, Alfred. 1949. Freedom Under the Law. London: Stevens \& Sons Limited.

Faiz, Pan Mohamad. 2016. "The Protection of Civil and Political Rights by the Constitutional Court of Indonesia." Indonesia Law Review 2: 158-179.

Fenwick, Stewart. 2017. Blasphemy, Islam and the State: Pluralism and Liberalism in Indonesia. Abingdon: Routledge.

Fiss, Joelle, and Jocelyn G. Kestenbaum. 2017. Respecting Rights? Measuring the World's Blasphemy Laws. U.S. Commission on International Religious Freedom.

Freedom House. 2010. Policing Belief: The Impact of Blasphemy Laws on Human Rights. George, Cherian. 2016. Hate Spin: The Manufacture of Religious Offence and its Threat to Democracy. Cambridge, MA and London: MIT Press.

Gunn, Geoffrey C. 2018. "Indonesia in 2017: Shoring up the Pancasila State." Asian Survey 58 (1): 166-173.

Halili. 2016. Supremasi Intoleransi: Kondisi Kebebasan Beragama/Berkeyakinan dan Minoritas Keagamaan di Indonesia 2016 [Supreme Intolerance: The State of Freedom of Religion/Faith and Religious Minorities in Indonesia 2016]. Jakarta: Pustaka Masyarakat Setara.

Harsono, Andreas. 2019. "Indonesia's President Urges Delay on Criminal Code Vote." Human Rights Watch. September 23. https://www.hrw.org/news/2019/09/ 23/indonesias-president-urges-delay-criminal-code-vote (Accessed September 24, 2019).

Hasyim, Syafiq. 2015. "Majelis Ulama Indonesia and Pluralism in Indonesia." Philosophy and Social Criticism 41(4-5): 487-495.

Hatherell, Michael, and Alistair Welsh. 2017. "Rebel with A Cause: Ahok and Charismatic Leadership in Indonesia." Asian Studies Review 41 (2): 174-190.

Hefner, Robert A. 2016. "Indonesia, Islam, and the New U.S. Administration." The Review of Faith and International Affairs 14 (2): 59-66.

Holzaepfel, Caleb. 2014. "Can I Say That? How an International Blasphemy Law Pits the Freedom of Religion Against the Freedom of Speech.” Emory International Legal Review 28(1): 597-648.

Ingber, Stanley. 1984. "The Marketplace of Ideas: A Legitimizing Myth.” Duke Law Journal 1 (1): 1-91.

Jones, Peter. 1980. "Blasphemy, Offensiveness and Law." British Journal of Political Science 10 (2): 129-148.

Kilcrease, Bethany. 2014. "Radical Anti-Catholic Protestantism and When It Was Dark: The Novel and the Historical Context." English Literature in Transition, 1880-1920 57 (2): 210-230.

Lawton, David. 1993. Blasphemy. Philadelphia: University of Pennsylvania Press. 
Lazuardi, Iqbal Tawakal. 2017. "Buni Yani Divonis 1.5 Tahun Penjara [Buni Yani Sentenced to 1.5 Years in Prison]." Tempo. November 14. https://nasional.tempo.co/ read/1033655/buni-yani-divonis-15-tahun-penjara (Accessed June 7, 2019).

Lea, Henry Charles. 1906. A History of the Inquisition of Spain, Volume I. New York: Macmillan.

Lim, Merlyna. 2017. "Freedom to Hate: Social Media, Algorithmic Enclaves, and the Rise of Tribal Nationalism in Indonesia." Critical Asian Studies 49 (3): 411-427.

Lindsey, Tim. 2012. "Monopolising Islam: The Indonesian Ulama Council and State Regulation of the "Islamic Economy'." Bulletin of Indonesian Economic Studies 48 (2): 253-274.

Lindsey, Tim, and Melissa Crouch. 2013. "Cause Lawyers in Indonesia: A House Divided." Wisconsin International Law Journal 31 (3): 620-645.

Lorch, Jasmin. 2019. "Islamization by Secular Ruling Parties: The Case of Bangladesh." Politics and Religion 12 (2): 257-282.

Marsh, Joss. 1998. Word Crimes: Blasphemy, Culture, and Literature in Nineteenth Century England. Chicago, IL and London: The University of Chicago Press.

McCargo, Duncan. 2012. Mapping National Anxieties: Thailand's Southern Conflict. Copenhagen: NIAS Press.

Menchik, Jeremy. 2014. "Productive Intolerance: Godly Nationalism in Indonesia." Comparative Studies in Society and History 56 (3): 591-621.

Mietzner, Marcus. 2017. "Indonesia in 2016: Jokowi's Presidency between Elite Consolidation and Extra-Parliamentary Opposition." Asian Survey 57 (1): 165-172.

Mietzner, Marcus. 2018. "Fighting Illiberalism with Illiberalism: Islamist Populism and Democratic Deconsolidation in Indonesia." Pacific Affairs 91 (2): 261-282.

Nash, David. 2007. Blasphemy in the Christian World: A History. Oxford: Oxford University Press.

Nastiti, Aulia, and Sari Ratri. 2018. "Emotive Politics: Islamic Organizations and Religious Mobilization in Indonesia." Contemporary Southeast Asia 40 (2): 196-221.

Olle, John. 2009. "The Majelis Ulama Indonesia Versus 'Heresy': The Resurgence of Authoritarian Islam." In State of Authority: The State in Society in Indonesia, eds. Gerry van Klinken and Joshua Barker. Ithaca, NY: Cornell Southeast Asia Program, 95-116.

Osman, Mohamad Nawab Mohamad, and Prashant Waikar. 2018. "Fear and Loathing: Uncivil Islam and Indonesia's Anti-Ahok Movement." Indonesia 106(October): 89109.

Peterson, Daniel. 2018. "Blasphemy, Human Rights, and the Case of Ahok." The Asian Yearbook of Human Rights and Humanitarian Law 2: 52-94.

Picard, Michel. 2011. "Introduction: 'Agama', 'Adat', and Pancasila." In The Politics of Religion in Indonesia: Syncretism, Orthodoxy, and Religious Contention in Java and Bali, eds. Michel, Picard and Remy Madinier. London and New York: Routledge, $1-20$.

Post, Robert C. 1988. "Cultural Heterogeneity and Law: Pornography, Blasphemy, and the First Amendment." California Law Review 76 (2): 297-335.

Prayoga, Andhika. 2015. "Breakfast Jurisprudence: Bagaimana Agama Dapat Memengaruhi Hakim Dalam Memutus Perkara Berdimensi Kebebasan Beragama dan Berkeyakinan [Breakfast Jurisprudence: How Religion Influences the Decisions of Judges in Cases with Religious and Faith Dimensions]." Jurnal Keadilan Sosial 5: 1-11.

Purdey, Jemma. 2006. Anti-Chinese Violence in Indonesia, 1996-1999. Honolulu: University of Hawai'i Press.

Schafer, Saskia. 2017. "Understanding Piety and Anger in Indonesia's 2016 Islamic Mass Rallies.” In Piety, Celebrity, Sociality: A Forum on Islam and Social Media in Southeast 
Asia, eds. Martin Slama and Carla Jones. American Ethnologist, November 8. http:// americanethnologist.org/features/collections/piety-celebrity-sociality/understandingpiety-and-anger-in-indonesias-2016-islamic-mass-rallies (Accessed June 7, 2019).

Setijadi, Charlotte. 2017. "Ahok's Downfall and the Rise of Islamist Populism in Indonesia." ISEAS Perspective 38: 1-9.

Shah, Dian A.H. 2014. "Constitutional Arrangements on Religion and Religious Freedom in Malaysia and Indonesia: Furthering or Inhibiting Rights?" The Indonesian Journal of International and Comparative Law 1: 260-299.

Sihombing, Uli Parulian, Pultoni Siti Aminah, and Muhammad Khoirul Roziqin. 2012. Ketidakadilan Dalam Beriman: Hasil Monitoring Kasus-Kasus Penodaan Agama dan Ujaran Kebencian atas Dasar Agama di Indonesia [The Godly Injustice: The Results of Monitoring Cases of Blasphemy and Religious Hate Speech in Indonesia]. Jakarta: The Indonesian Legal Resources Centre.

Singghi, Emanuel Gerrit. 2019. "What has Ahok to do with Santa? Contemporary Christian and Muslim Public Theologies in Indonesia." International Journal of Public Theology 13 (1): 25-39.

Stanghellini, Geovanni. 2017. Lost in Dialogue: Anthropology, Psychopathology, and Care. Oxford: Oxford University Press.

Strang, Robert R. 2008. "'More Adversarial, but Not Completely Adversarial': Reformasi of the Indonesian Criminal Procedure Code." Fordham International Law Journal 32 (1): 188-231.

Streckfuss, David. 2011. Truth on Trial in Thailand: Defamation, Treason, and LèseMajesté. Abingdon: Routledge.

Sumaktoyo, Nathanael. 2017. "Ethnicity and Jakarta's Election." New Mandala. February 13. http://www.newmandala.org/ethnicity-jakartas-election/ (Accessed June 7, 2019).

Suryadinata, Leo. 2017. "General Gatot and the Re-emergence of Pribumi-ism in Indonesia." ISEAS Perspectives 49: 1-7.

Suryadinata, Leo. 2019. "Identity Politics in Indonesia: The Meliana Case." ISEAS Perspectives 4: 1-8.

Telle, Kari. 2018a. "Blasphemy and 'Hate Spin' Campaigns in Indonesia." The Immanent Frame. December 14. https://tif.ssrc.org/2018/12/14/blasphemy-and-hate-spin-campaignsin-indonesia/ (Accessed September 24, 2019).

Telle, Kari. 2018b. "Faith on Trial: Blasphemy and 'Lawfare' in Indonesia." Ethnos 83 (2): 371-391.

Theodorou, Angelina E. 2016. "Which Countries Still Outlaw Apostasy and Blasphemy?" Pew Research Center July 29. http://www.pewresearch.org/fact-tank/2016/07/29/ which-countries-still-outlaw-apostasy-and-blasphemy/ (Accessed June 7, 2019).

Thorne, Guy. 1903. When It Was Dark. London: Greening.

Tomsa, Dirk. 2017. "Indonesia in 2016: Jokowi Consolidates Power." In Southeast Asian Affairs 2017, eds. Malcolm Cook and Daljit Singh. Singapore: ISEAS, 149-162.

Van Bruinessen, Martin. 2013. "Introduction: Contemporary Developments in Indonesian Islam and the 'Conservative Turn' of the Early Twenty-First Century." In Contemporary Developments in Indonesian Islam: Explaining the "Conservative Turn", ed. Martin van Bruinessen. Singapore: ISEAS, 1-20.

Wilson, Ian. 2016. "Out of the Rubble: Jakarta's Poor and Displaced Seek a Vehicle for their Voice." Indonesia at Melbourne. October 4. https://indonesiaatmelbourne. unimelb.edu.au/out-of-the-rubble-jakartas-poor-and-displaced-seek-a-vehicle-for-theirvoice/ (Accessed June 7, 2019). 